\title{
Versões e controvérsias sobre 1964 e a ditadura militar
}

Carlos Fico $^{1}$

UFRJ

\section{Resumo}

O principal objetivo deste artigo é expor e discutir as mais importantes correntes da historiografia sobre o Golpe de 1964 e confrontar algumas questões controvertidas sobre repressão política, censura e outros temas da ditadura militar. Palavras-chave: Historiografia; Golpe de Estado; Ditadura militar.

\begin{abstract}
The main purpose of this article is to present and discuss the principal trends of historiography or Brazilian 1964 coup d'état and discuss some controversial questions censorship, political repression and other subjects concerning Brazilian military dictatorship history.

Keywords: Historiography; Brazilian coup d'État; Dictatorship History.
\end{abstract}

\section{EFEMÉRIDES}

Em 7 de setembro de 1972, a ditadura militar tomou conta das comemorações da principal efeméride do período: o Sesquicentenário da Independência do Brasil. As festas tiveram um caráter oficial e algo sombrio: o general Médici presidiu um desfile na avenida Paulista, vendedores ambulantes ofereciam monóculos com a fotografia de dom Pedro I e o principal ato simbólico da comemoração foi a lúgubre cerimônia de translação de parte do corpo do imperador (o coração ficou em Portugal) para a capela do Monumento do Ipiranga depois de os despojos mortais terem peregrinado por todo o país.

Não é cabível celebrar um golpe de Estado como o de 31 de março de 1964, mas estes quarenta anos também podem ser caracterizados como uma efeméride, se pensarmos no sentido que a expressão assumiu para os historiadores brasileiros, principalmente a partir de meados dos anos 80 - depois do fim do regime militar —, quando tivemos o Bicentenário da Conjuração Mineira (no mesmo ano do Bicentenário da Revolução Francesa), o Centenário da Abolição da Escravidão e o da Proclamação da República, apenas para citar as mais importantes. Muitos eventos e publicações marcaram as da- 
tas, fomentando pesquisas, debates e revisões. $\mathrm{O}$ ano de 2004 é pontuado por aniversários importantes, como os cinqüenta anos do atentado da rua Tonelero e do suicídio de Getúlio Vargas ou os vinte das “Diretas, Já!”, campanha lançada em 1983, mas que cresceu em 1984. Portanto, é muito oportuno que aproveitemos para fazer um balanço da produção relacionada a 1964 (e seus desdobramentos) - efeméride aqui entendida como fato importante, embora não grato.

Tem sido notável, neste ano, o interesse despertado pelos eventos de toda sorte que vão marcando a data, diferentemente de dez anos atrás, quando seminários acadêmicos sobre os trinta anos do golpe de 64 tiveram de ser cancelados ou contaram com baixa freqüência de público. Milhares de pessoas, na maioria jovens, têm comparecido a debates em todo o Brasil. A imprensa acompanha com interesse atividades acadêmicas regra geral ignoradas. Várias publicações voltadas para o tema têm sido lançadas. Qual a causa de tamanha aceitação? A explicação certamente fundamenta-se no fato de que velhos mitos e estereótipos estão sendo superados, graças tanto à pesquisa histórica factual de perfil profissional quanto ao que poderíamos caracterizar como um "desprendimento político" que o distanciamento histórico possibilita: tabus e ícones da esquerda vão sendo contestados sem que tais críticas possam ser classificadas de "reacionárias". Processa-se uma mudança geracional, sendo cada vez mais freqüente que pesquisadores do tema não tenham parti pris. Nesse sentido, tem sido destacado o pequeno apreço dos principais atores históricos do período do golpe de 64 pela democracia (inclusive a esquerda); ${ }^{2}$ o "deslocamento de sentido", operado sobretudo após a Campanha da Anistia, relativo às esquerdas revolucionárias que foram para a luta armada, outrora apresentadas como integrantes da resistência democrática; ${ }^{3}$ o perfil vacilante, a inabilidade e o possível golpismo de João Goulart, diferentemente do mito do presidente reformista vitimado por reacionários, ${ }^{4} \mathrm{e}$ assim por diante. Ao mesmo tempo, clichês sobre o golpe de 64, os militares e o regime também vão sendo abandonados, como a idéia de que só após 1968 houve tortura e censura; a suposição de que os oficiais-generais não tinham responsabilidade pela tortura e o assassinato político, ${ }^{5}$ a impressão de que as diversas instâncias da repressão formavam um todo homogêneo e articulado, ${ }^{6}$ a classificação simplista dos militares em "duros" ou “moderados” etc. Por tudo isso, podemos falar de uma nova fase da produção histórica sobre o período.

Também é crescente o interesse de jovens historiadores e de estudantes de cursos de graduação em história pelos temas do período 1964-1985. A op- 
ção radicaliza, por assim dizer, o acerto da hipótese avançada pelo saudoso José Roberto do Amaral Lapa, quando previu, ainda em 1976, que o predomínio dos estudos sobre a fase colonial seria suplantado pelas pesquisas sobre o período republicano. ${ }^{7}$ Ele falava em uma espécie de "conspiração anticontemporânea”, pois, até aquela época, catedráticos passadistas induziam ou quase impunham - o estudo dos fatos históricos mais remotos, enobrecidos pela pátina do tempo. Num primeiro momento (anos 80), avultaram os estudos sobre a Primeira República, destacando temas como o surgimento do movimento operário. Hoje em dia, é notável a quantidade de pesquisas sobre questões recentíssimas da história do Brasil, o que deve ter sido estimulado pelo interesse que a "melancólica trajetória nacional" contemporânea como dizia o também saudoso Francisco Iglésias ${ }^{8}$ - suscita.

A abordagem propriamente histórica da ditadura militar é recente. Poderíamos dizer que se trata de uma espécie de movimento de incorporação, pelos historiadores, de temáticas outrora teorizadas quase exclusivamente por cientistas políticos e sociólogos e narradas pelos próprios partícipes. De fato, a literatura sobre o golpe de 64 e o regime que o sucederia ficaria marcada, em uma primeira fase, por dois importantes gêneros. $O$ primeiro foi uma espécie de politologia: inspirados sobretudo pela vertente norte-americana da Ciência Política, muitos estudiosos buscaram explicar e classificar, em termos quase nominalistas, as crises militares de países como o Brasil. Seriam os militares uma instituição autônoma, marcada pelo isolamento e unidade, ou estariam a serviço de determinados grupos sociais? Um único modelo teórico daria conta de explicar, por exemplo, os regimes militares latino-americanos? Haveria alguma singularidade no caso brasileiro? Esses debates, que produziram expressiva bibliografia, nunca chegaram a verdadeiramente animar os historiadores, mas pelo menos uma contribuição significativa para o entendimento do golpe foi dada por essa corrente — como se verá.

O segundo gênero predominante no que poderia ser caracterizado como primeira fase dos estudos sobre o período foi a memorialística, que cresceu sobretudo a partir da distensão política patrocinada pelo governo de Ernesto Geisel. Foi, de algum modo, a primeira tentativa de construção de uma narrativa histórica sobre o período, embora já existisse uma ou outra incursão nesse sentido, especialmente no que se refere ao governo Goulart e sua ruína. ${ }^{9}$ Foi essa memorialística que constituiu o primeiro conjunto de versões sobre a ditadura militar, algumas das quais se revelariam mitos ou estereótipos. Do ponto de vista oficial, livros como os de Luís Viana Filho, chefe da Casa Civil de Castelo Branco, e de Daniel Krieger, líder do governo no Sena- 
do, ${ }^{10}$ serviram para construir o perfil do primeiro general-presidente como "moderado" e "legalista". Pouco tempo depois sairiam os de Jayme Portella de Mello e Hugo Abreu, ${ }^{11}$ destacando diferenças que desmentiam a unidade militar. Do lado da esquerda, depoimentos como os de Fernando Gabeira e Alfredo Sirkis ${ }^{12}$ - que foram grandes sucessos editoriais - contribuiriam para a mitificação da figura do ex-guerrilheiro, por vezes tido como um ingênuo, romântico ou tresloucado, diluído no contexto cultural de rebeldia típico dos anos 60 , algo que não condiz com as efetivas motivações da assim chamada "luta armada" - expressão que, diga-se, traduz mal as descontinuadas e incertas iniciativas militares da esquerda brasileira de então, pois, nas cidades, tais incursões mais se assemelhavam a algum tipo de contrapropaganda, tendo o aspecto de crimes comuns (assaltos a bancos e seqüestros) e, no campo, ficaram marcadas pela inépcia e caráter absconso, nada obstante, infelizmente, terem causado a morte de muitas pessoas.

\section{CONTROvÉrsias}

As mencionadas "moderação" de Castelo e transmutação da "luta armada" em "resistência democrática" são apenas dois exemplos de lista bem mais extensa de conflitos suscitados pela memorialística. Poderíamos falar de um esgotamento do gênero? Com o passar do tempo, é natural que os depoimentos rareiem e de algum modo tornem-se iterativos, sendo este o caso, por exemplo, dos testemunhos sobre a "luta armada". Segundo Jacob Gorender, "do lado da esquerda, certamente não estão esgotadas as fontes capazes de fornecer revelações significativas, mas o principal já foi extraído dessas fontes. Ficaram por esclarecer detalhes, sobretudo concernentes a atuações individuais". ${ }^{13}$ Não se trata de desqualificar o gênero, mas de bem entendê-lo, pois as memórias (oficiais, da esquerda e de outros grupos sociais) são antes objetos de análise do que fontes de acesso a uma suposta versão verdadeira. Vejamos algumas versões que, por repetição, fixaram-se no senso comum como aceitas.

Reiteradamente caracterizado como "legalista" e "moderado", o perfil de Castelo Branco serviu até mesmo para adjetivar um conjunto de militares que com ele partilhariam uma formação intelectual mais refinada (diferentemente dos troupiers, propensos a ações práticas e métodos violentos), um apego às normas legais e uma forma mais branda de tratar os inimigos da "revolução". Atributos tão atraentes parecem derivar muito mais da benevolência dos 
biógrafos que o beneficiaram do que propriamente de uma análise do desempenho do primeiro general-presidente. Castelo Branco, como se sabe, foi escolhido para a Presidência da República contra a vontade do general Costa e Silva, que, nas primeiras horas após o golpe, autonomeara-se "comandanteem-chefe do Exército Nacional” e líder do "Comando Supremo da Revolução". Se a escolha de seu nome (que o próprio Castelo articulou com competência entre políticos civis) impediu a imediata ascensão de Costa e Silva (nomeado "apenas" ministro da Guerra), durante o seu governo Castelo não conseguiu, como pretendia, interromper a temporada de punições "revolucionárias"; proibiu atividades políticas dos estudantes; decretou o AI-2; não logrou impedir que militares radicais conquistassem poder político; ajudou a redigir e assinou a Lei de Segurança Nacional que instituiu a noção de "guerra interna”; fechou o Congresso Nacional e decretou uma Lei de Imprensa restritiva. Além de tudo, foi conivente com a tortura, que já era praticada nos primeiros momentos após o golpe (é costume afirmar-se que a tortura só se tornaria freqüente no pós-68). De fato, diante das acusações que irrompiam na imprensa, Castelo viu-se obrigado a mandar seu chefe da Casa Militar o futuro presidente Ernesto Geisel — averiguar os fatos. Geisel voltou tergiversando e Castelo omitiu-se. Como se não bastasse, teve de admitir ser sucedido por aquele que se tornara o condestável de seu governo — precisamente o general Costa e Silva.

A contestação dessa leitura corrente sobre a "moderação" de Castelo não é apenas mais uma disputa de memória, pois, felizmente, hoje, ampara-se em pesquisas profissionalmente conduzidas. ${ }^{14}$ Trata-se de um pressuposto básico para firmar-se uma interpretação que se baseia em pesquisas ainda incipientes: o entendimento do regime militar como o da trajetória de surgimento, ascensão, auge e decadência do setor conhecido como linha dura. Terá sido o fracasso de Castelo de pôr cobro aos anseios punitivos de militares radicalizados que fomentou o crescimento do que então se chamava de "força autônoma", que se autonomeara verdadeira guardiã dos princípios da "revolução", e que se tornaria, paulatinamente, um grupo de pressão muito eficaz (capaz, por exemplo, de reabrir a temporada de punições com o Ato Institucional $\mathrm{n}^{\mathrm{o}}$ 2, em 27 de outubro de 1965) e, posteriormente, institucionalizar-se-ia como as famosas "comunidade de segurança" e "comunidade de informações". Castelo foi complacente com as arbitrariedades da linha dura, não teve forças para enfrentá-la e permitiu, assim, que o grupo de pressão fosse conquistando, paulatinamente, mais espaço e poder. Essa evolução é essencial para bem caracterizar diversos outros episódios do período, pois informa que o projeto 
repressivo baseado numa "operação limpeza” violenta e longeva estava presente desde os primeiros momentos do golpe. Assim, o Ato Institucional no 5 foi o amadurecimento de um processo que se iniciara muito antes, e não uma decorrência dos episódios de 1968, diferentemente da tese que sustenta a metáfora do "golpe dentro do golpe", segundo a qual o AI-5 iniciou uma fase completamente distinta da anterior. Trata-se de reafirmar a importância, como projeto, do que se pode chamar de "utopia autoritária", ${ }^{15}$ isto é, a crença de que seria possível eliminar quaisquer formas de dissenso (comunismo, "subversão", "corrupção") tendo em vista a inserção do Brasil no campo da "democracia ocidental e cristã".

Tal crença empolgava de maneira diferente os diversos grupos militares, sendo também uma simplificação forjada pelas primeiras e mais apressadas leituras a dicotomia "linha dura" versus "moderados" (ou "castelistas"). Os militares (e os civis) diretamente envolvidos em tortura e assassinato político foram poucos. Eram aqueles que, após 1968, integravam as turmas de captura e interrogatório do sistema Codi-Doi ou suas equivalentes das instâncias estaduais da repressão (Dops), além dos centros de informações dos ministérios militares. Essa percepção não é uma forma de minimizar o envolvimento dos militares com a repressão violenta, mas uma maneira de refinar a análise que se possa fazer do período, pois é óbvio que muitos militares aderiram à "utopia autoritária" admitindo a tortura e o extermínio (como é o caso do ex-presidente Ernesto Geisel, tido como moderado) sem praticar martírios com as próprias mãos. Outros também eram adeptos do pensamento segundo o qual deveriam ser eliminados os "óbices" ao "objetivo nacional permanente" de transformação do Brasil em uma potência mundial, mas essa eliminação deveria pautar-se por critérios não violentos. Alguns não aderiam a tal projeto, sobretudo jovens oficiais da metade final da ditadura que permaneciam omissos, preferindo cuidar de suas carreiras. Havia, igualmente, militares decididos a passar para a reserva caso fossem instados a acobertar atos de tortura, ${ }^{16}$ mas foram poucos os casos de denúncia ou oposição explícita, o que revela a existência de uma grande quantidade de militares coniventes. Existem muitas tentativas acadêmicas de criação de uma tipologia dos grupos militares, tarefa algo difícil, como se vê pela multiplicidade de exemplos listados, mas certamente deve ser abandonada a divisão duros/moderados. Até porque a posição em relação à tortura é apenas um dos critérios possíveis de classificação, havendo a necessidade de também se considerar outros fatores, como formação militar, laços de lealdade e posição em relação ao desenvolvimento econômico do país. Como se sabe, há diferenças significativas en- 
tre militares formados nesta ou naquela instituição, tanto quanto havia bastante controvérsia quanto ao papel do capital estrangeiro no crescimento do Brasil. Aspecto ainda mais complexo, as redes de lealdade que se estabelecem entre camaradas de caserna muitas vezes suplantam ou ignoram diferenças políticas ou ideológicas. ${ }^{17}$

Certamente, porém, o posicionamento em relação à repressão violenta é um dos aspectos mais importantes para se entender os grupos militares de então. Guarda relação direta com esse tema a idéia, muito repetida nas memórias de militares, segundo a qual a tortura e o extermínio seriam da responsabilidade de subalternos, praticantes de excessos que teriam constituído um modo desvirtuado de levar a cabo a repressão, sem a aprovação dos oficiaisgenerais - tese que chegou a ser admitida por analistas importantes..$^{18} \mathrm{~A}$ versão talvez possa ser admitida para os primeiros momentos após o golpe, quando houve a necessidade da já mencionada Missão Geisel. Mas ela não se sustenta para o período posterior ao AI-2 e, sobretudo, à implantação do Sistema Codi-Doi (1969 em diante). Como se sabe, esse sistema implantou uma polícia política bastante complexa no país - que mesclava polícia civil, polícia militar, militares das três forças e até mesmo bombeiros e polícia feminina - e foi responsável pelos principais episódios de tortura e extermínio. Representou a vitória completa da antiga "força autônoma". As turmas de busca e interrogatório faziam o trabalho sujo que a "utopia autoritária" pressupunha. ${ }^{19}$

Assim, em função de suas necessidades intrínsecas, essa polícia política atuava com grande liberdade de ação, até mesmo porque não poderia ser de outra forma, sob pena de perder oportunidades, quebrar o sigilo de operações secretas etc. Mas não se deve confundir a independência operacional com que trabalhava a polícia política com uma suposta autonomia em relação aos oficiais-generais. A tortura e o extermínio eram aceitos pelos comandantes e governos militares, como hoje já se comprovou. Curiosamente, tanto para os linhas-duras apenas “ideológicos” (militares radicalmente contrários à "subversão" mas que não atuavam diretamente na repressão) quanto para os pragmáticos rigorosos (supostos moderados, como Ernesto Geisel, que no entanto admitiam a tortura e o assassinato como necessidade conjuntural), a tortura tinha o mesmo significado: era um "mal menor". Seguramente cabe nuançar a questão, pois é certo que, na cabeça de alguns militares, havia diferenças entre matar um guerrilheiro no Araguaia e torturar um estudante comunista preso no Rio ou em São Paulo. Este é um aspecto importante para a consideração, por exemplo, da lamentável conversa, revelada por Elio Gaspari, que Ernesto Geisel teve com o general Dale Coutinho quando o convidou para 
ser seu ministro do Exército. ${ }^{20}$ Mas a tese dos “excessos", hoje em dia, é apenas uma tópica de um discurso fraudulento. Conta, até mesmo - como todo bom estereótipo —, com premonições: o vice-presidente Pedro Aleixo, quando da reunião do Conselho de Segurança Nacional que aprovou o AI-5, disse não temer a aplicação do Ato pelas "mãos honradas" de Costa e Silva, mas a atuação do "guarda de esquina". Ao contrário, hoje podemos afirmar, baseados em evidências empíricas, que a tortura e o extermínio foram oficializados como práticas autorizadas de repressão pelos oficiais-generais e até mesmo pelos generais-presidentes.

A distinção que hoje se pode fazer entre a espionagem (ou "comunidade de informações") e a polícia política (ou "comunidade de segurança”) também tem colaborado para esclarecer outros estereótipos. De fato, tornou-se comum afirmar-se a existência de certa homogeneidade dessas instâncias repressivas, que comporiam os "porões da ditadura". Embora fossem todas articuladas, tinham suas diferenças e funcionavam segundo parâmetros diferenciados. Penso que só o estudo conjunto dos pilares básicos da repressão (espionagem, polícia política, censura da imprensa, censura de diversões públicas, propaganda política e julgamento sumário de supostos corruptos) permite compreender que, a partir de 1964, gestou-se um projeto repressivo global, fundamentado na perspectiva da "utopia autoritária", segundo a qual seria possível eliminar o comunismo, a "subversão", a corrupção etc. que impediriam a caminhada do Brasil rumo ao seu destino de "país do futuro". A leitura segundo a qual a montagem de tal aparato repressivo decorreu da conjuntura de 1968 e deu-se de maneira reativa (em relação à chamada "luta armada") ou aleatória não parece ser a melhor. Tal projeto forjou-se na fase dos primeiros IPMs de 1964, a partir do descontentamento dos integrantes da então "força autônoma" (embrião da linha dura) com a morosidade das punições aplicadas por Castelo Branco durante a primeira "Operação Limpeza”.

O SNI foi criado ainda em 1964, com propósitos mais modestos do que os que assumiria a partir de março de 1967, quando, de produtor de informações para subsidiar as decisões do presidente da República, transformouse, sob a chefia do general Emílio Garrastazu Médici, em cabeça de uma ampla rede de espionagem. Ao contrário do que supôs Golbery do Couto e Silva, que afirmou ter criado "um monstro", não foi ele, mas a linha dura, que gestou tal criatura. A vitória definitiva da corrente, representada pela decretação do AI-5, fez com que a espionagem passasse a atuar a serviço dos setores mais radicais, divulgando as avaliações que justificavam a escalada e a manutenção da repressão. Porém, mesmo com o "endurecimento" do SNI a partir de Mé- 
dici, o órgão e suas representações nos ministérios civis (as divisões de segurança e informações, então remodeladas e fortalecidas) persistiram como produtores de informações, não se envolvendo diretamente nas "operações de segurança”, eufemismo que designava as prisões, interrogatórios, torturas e extermínios, praticados pelo "Sistema Codi-Doi", pelos órgãos de informações dos ministérios militares (Cie, Cisa e Cenimar) e pelos departamentos de ordem política e social estaduais.

Portanto, é fundamental destacar que, se o anseio punitivo que caracterizava a linha dura não surgiu repentinamente em 1968, como reação à opção de parte da esquerda pela chamada "luta armada", de fato, a partir do AI5 , as diversas instâncias repressivas já existentes passaram a agir segundo o ethos da comunidade de segurança e de informações ou com ela entraram em conflito. No primeiro caso, está a censura de diversões públicas; no segundo, a propaganda política. Vejamos rapidamente os dois casos.

Não houve uma censura durante o regime militar, mas duas. A censura da imprensa distinguia-se muito da censura de diversões públicas. A primeira era "revolucionária", ou seja, não regulamentada por normas ostensivas. ${ }^{22}$ Objetivava, sobretudo, os temas políticos stricto sensu. Era praticada de maneira acobertada, através de bilhetinhos ou telefonemas que as redações recebiam. A segunda era antiga e legalizada, existindo desde 1945 e sendo familiar aos produtores de teatro, de cinema, aos músicos e a outros artistas. Era praticada por funcionários especialistas (os censores) e por eles defendida com orgulho. Amparava-se em longa e ainda viva tradição de defesa da moral e dos bons costumes, cara a diversos setores da sociedade brasileira. Durante a ditadura houve problemas e contradições entre tais censuras. A principal foi a penetração da dimensão estritamente política na censura de costumes - justamente em função da mencionada vitória da linha dura caracterizada pelo AI-5. Aliás, tal politização da censura de diversões públicas por vezes transpareceu a impressão de unicidade das censuras durante o período. Curiosamente, houve grande diferença entre as fases mais punitivas de uma e de outra. A censura da imprensa acompanhou o auge da repressão (quando se pensa em cassações de mandatos parlamentares, suspensões de direitos políticos, prisões, torturas e assassinatos políticos) que se verificou entre finais dos anos 60 e início dos anos 70. A censura de diversões públicas, porém, teve seu auge no final dos anos 70, já durante a "abertura". ${ }^{23}$ Diga-se de passagem que essa distinção chama a atenção para a necessidade de maiores pesquisas sobre fenômenos não explicitamente políticos (em sentido estrito), se quisermos entender globalmente o período que, muitas vezes, tem 
sido subsumido nesta esfera. De fato, a história do Brasil entre 1964 e 1985 não se restringe à história da ditadura militar. Em relação ao problema da censura de diversões públicas, por exemplo, sobrelevam, evidentemente, os conflitos entre setores mais conservadores da sociedade de então e questões referidas às mudanças comportamentais (como o movimento hippie, a liberalização das práticas sexuais e as manifestações artístico-culturais das "vanguardas”). Do mesmo modo, a perspicácia da TV Globo a levou a criar o inovador produto que foi a novela de perfil realista-naturalista retratando, sobretudo, a vida urbana das grandes cidades brasileiras, gerando alguns dos maiores problemas de censura de costumes do período.

Se a censura de diversões públicas teve de incorporar à sua tradicional temática de defesa da moral e dos bons costumes os ingredientes políticos impostos pela vitória da linha dura, outras instâncias, como a propaganda política, passaram por uma dinâmica de confronto. Desde 1964, assessores militares pretenderam criar uma agência de propaganda política, mas isso somente se deu em janeiro de 1968, com a criação da Assessoria Especial de Relações Públicas - Aerp. A partir de então, a Aerp encheria a TV com seus filmes enaltecendo o amor, a participação, a crença no "Brasil potência" etc. ${ }^{24}$ Porém, ao contrário do que se poderia supor, a Aerp não contava com a simpatia da linha dura. A Assessoria era vista como uma agência desimportante e seus filmes, como coisa supérflua. Para a linha dura, a mensagem que deveria ser passada à população não era a exaltação otimista do "Este é um país que vai pra frente", mas outra, mais radical, como os discursos de arrependimento de militantes da luta armada feitos prisioneiros, transmitidos pela TV, ou o famoso slogan "Brasil: ame-o ou deixe-o", iniciativas da polícia política que preferia afirmar-se pela força de uma "guerra psicológica" e não pela propaganda edulcorada da Aerp.

Se havia essas diferenças, como o sistema repressivo pôde ter funcionalidade? Uma resposta possível é a consideração da já mencionada "utopia autoritária” como cimento ideológico que agregava todas as instâncias. Para muitos analistas, esse papel teria sido desempenhado pela chamada "doutrina de segurança nacional”. A doutrina era um conjunto não muito criativo de considerações geopolíticas que, tendo em vista certas premissas óbvias (tamanho do país e de sua população e vulnerabilidade à convulsão social), perseguiam o objetivo do "Brasil potência". A principal recomendação da doutrina era o combate interno ao comunismo. Talvez possamos dizer que a "utopia autoritária" seja uma forma menos elaborada e intelectualmente diluída da doutrina. Mas é preciso não perder de vista que a antiga tradição bra- 
sileira de pensamento autoritário inspira ambas e que a propaganda anticomunista precede em muito a ditadura militar. A mencionada utopia assentava-se na crença em uma superioridade militar sobre os civis, vistos, regra geral, como despreparados, manipuláveis, impatrióticos e - sobretudo os políticos civis - venais. Penso que ela se realizava em duas dimensões: a primeira, mais óbvia, de viés saneador, visava "curar o organismo social" extirpando-lhe fisicamente o "câncer do comunismo". A segunda, de base pedagógica, buscava suprir supostas deficiências da sociedade brasileira. Assim, enquanto a polícia política, a espionagem, a censura da imprensa e o julgamento sumário de supostos corruptos estavam fortemente imbuídos da dimensão saneadora da "utopia autoritária", a Aerp e a DCDP primavam pela tópica pedagógica. Enquanto os primeiros eliminavam, mesmo fisicamente, comunistas, "subversivos" e "corruptos", as duas últimas buscavam "educar o povo brasileiro" ou defendê-lo dos ataques à "moral e aos bons costumes". Como é fácil perceber, as duas dimensões podem aparecer combinadas numa mesma instância, sendo flagrante que a Comissão Geral de Investigações (responsável pelo julgamento sumário de acusados de corrupção) tanto atuava no saneamento (caçando e cassando supostos corruptos), quanto pretendia exercer uma prática educativa (através do que era chamado de "ações catalíticas”, práticas intimidatórias caracterizadas pela convocação arbitrária de pessoas que eram advertidas sobre possíveis punições futuras).

Quase todos os militares remanescentes do golpe (pois muitos foram afastados em 1964) estavam identificados com a "utopia autoritária", mas sua adesão a tal projeto variava conforme prevalecesse uma ou outra dimensão. Assim, foram constantes os choques entre algumas dessas instâncias, mas algum grau de violência era admitido por todos e a comunidade de informações teve função muito importante na propagação da defesa da necessidade da repressão stricto sensu, mas também da censura, do combate à corrupção, da utilização dos meios de comunicação para a propaganda etc.

\section{PRODUÇÃO RECENTE}

A produção histórica que marca a nova fase de estudos sobre a ditadura militar possui suas peculiaridades. Boa parte dela foi feita no contexto da chegada da "Nova História" ao país, ou, dizendo melhor, não viria a ser uma produção fortemente influenciada pelo marxismo ou pela segunda fase dos Annales. Porém, no campo dos estudos especificamente históricos (diferentemente 
de áreas como a Ciência Política), a crítica ao marxismo não se fixou na contraposição entre as hipóteses (teóricas) da determinação das estruturas econômico-sociais e a da autonomia do sistema político, mas na valorização do indivíduo e de sua subjetividade em oposição às leituras "tradicionais" (marxistas ou dos Annales dos anos 50 e 60) de cunho estrutural. Assim, abandonando explicações fundadas em conceitos como os de "classe social", "modo de produção", "estrutura econômica" ou "estrutura social”, os historiadores do que se convencionou chamar de "Nova História" buscaram uma estratégia cognitiva (mais do que uma perspectiva teórico-conceitual) que enfatizasse o indivíduo, seu cotidiano, suas emoções, sua "mentalidade", sua "trajetória de vida" etc., opções que, obviamente, não incidiram apenas sobre os estudos relativos à ditadura militar, mas sobre todo o escopo de estudos históricos aqui e alhures. Desse modo, o virtual abandono do marxismo pelos historiadores (que, no Brasil, se verificou a partir de meados dos anos 80 ) não se fundou tanto em uma crítica que cotejasse as insuficiências teóricas da perspectiva (notadamente o "determinismo economicista"), mas na constituição de um novo padrão de narratividade, motivado não mais pela pretensão rankeana de "mostrar como realmente aconteceu", mas na estratégia cognitiva mencionada: a valorização da subjetividade, do cotidiano etc., através de versões verossímeis que não almejam firmar-se como verdade absoluta, concatenadas, quanto possível, em narrativas saborosas. Isso talvez explique, por exemplo, a grande quantidade de trabalhos sobre o tema da cultura durante o regime militar, já que o enfoque cultural é o favorito entre os historiadores de algum modo referidos às correntes da "Nova História". É fácil perceber nessa inflexão (que chegou mesmo a ser conhecida como "crise da história", tamanho foi o impacto causado entre os historiadores) ecos da tradição conhecida como "crise da razão moderna", que, em uma de suas vertentes, chamava a atenção precisamente para o fato de, na vida moderna, o sujeito estar sendo paulatinamente anulado pelo crescente aumento da "burocratização", pela dimensão "instrumental" da racionalidade moderna — pautada em fins imediatos e não em valores universais —, pelas restrições impostas ao "mundo da vida” etc. Não é o caso, aqui, de discutir as fragilidades de tais concepções ou os acertos e desacertos da "Nova História". Esta última, por exemplo, envolve inúmeras correntes, algumas discrepantes entre si. Mas o fato é que foi nesse contexto que os estudos históricos sobre o período 1964-1985 se avolumaram.

Segundo levantamentos do Grupo de Estudos sobre a Ditadura Militar da UFRJ, entre 1971 e 2000 foram produzidas 214 teses de doutorado e dis- 
sertações de mestrado sobre a história da ditadura militar, 205 delas no Brasil e as restantes no exterior. ${ }^{25} \mathrm{O}$ crescimento paulatino do número de estudos sobre a temática é visível cotejando-se a produção de teses e dissertações em alguns qüinqüênios: no período 1971-1975 foram defendidos apenas dois trabalhos; entre 1986 e 1990 as defesas chegaram a 47; no final do período, entre 1996 e 2000, registraram-se 74 teses e dissertações. Os principais focos de interesse foram os movimentos sociais urbanos (27 trabalhos), os temas da arte e da cultura (também com 27 trabalhos), a economia (25) e os assuntos relacionados à esquerda e à oposição em geral (20 teses e dissertações). Em seguida vêm a imprensa (15), a censura (13), a crônica dos diversos governos (11), o movimento estudantil (8) e o estudo do próprio golpe (6), entre outros temas. Como boa parte dos trabalhos sobre a economia foi gerada na área própria, sobressai, como interesse dos historiadores, a temática da arte e da cultura, como já dito. Mas a grande presença de teses e dissertações sobre os movimentos sociais urbanos talvez indique a transição entre o antigo predomínio acadêmico do marxismo e a voga em torno da "Nova História" — haja vista que o enfoque predominante entre os trabalhos sobre o movimento operário, sindicatos etc. é o marxismo e seus influxos. Porém, mesmo nesse campo, é sintomático que algumas teses sobre o movimento operário, sobretudo as defendidas a partir do ano 2000, apresentem abordagens típicas da "Nova História”, como a memória e as práticas culturais ou o recurso a fontes nãoconvencionais, como a charge. Já entre os estudos que privilegiam a arte e a cultura, sobressaem as análises sobre a música (10 trabalhos de um total de 27), mesmo sem considerarmos outros dois sobre o tropicalismo, caso queiramos conceder que a corrente foi algo mais do que música. Abordagens sobre literatura e TV foram três, cada; sobre o teatro há apenas dois trabalhos. A velha máxima de que a história é feita com os olhos do presente parece presidir esses números: o interesse dos que foram partícipes de uma conjuntura de predomínio do ideal político revolucionário parece ceder lugar à valorização de outros autores, que participaram, como atores, da fase final da ditadura militar, durante a qual foram bastante valorizadas todas as instâncias da resistência democrática, mesmo as mais singelas, como a adesão a um manifesto de protesto, a freqüentação de uma dramaturgia denuncista ou a audição coletiva das músicas de protesto.

Se quisermos considerar uma hipótese prospectiva sobre o desenvolvimento futuro dos estudos históricos sobre a ditadura militar, certamente teremos de ter em mente o grande impacto que já vai causando a abertura de acervos de documentos sigilosos diretamente produzidos pelos sucessivos go- 
vernos militares. Refiro-me, principalmente, aos documentos dos diversos Dops, aos papéis da Divisão de Segurança e Informações do Ministério da Justiça (custodiados pelo Arquivo Nacional) e ao material sobre a censura produzido pela Divisão de Censura de Diversões Públicas (que está na sede do Arquivo Nacional em Brasília). Recentemente, o Departamento de Polícia Federal prometeu abrir seu acervo sobre o período militar. Embora já possamos ter acesso parcial a esses papéis, dois grandes acervos permanecem inacessíveis, embora conheçamos sua existência: o do Conselho de Segurança Nacional e o do Serviço Nacional de Informações. Como é sabido, na antevéspera da posse de Luís Inácio Lula da Silva na Presidência da República, Fernando Henrique Cardoso revogou, em aparente acordo com Lula, decreto que regulamentava a lei nacional de arquivos e impôs outro, draconiano no que se refere aos prazos de sigilo, que, então, foram duplicados.

\section{CAUSAS DO GOLPE}

Em se tratando de marcar os quarenta anos do golpe de 1964, cabe uma breve reflexão sobre as principais teses explicativas do fenômeno. Os trabalhos mais sólidos podem ser agrupados em três correntes: as tentativas de teorização da Ciência Política, as análises marxistas e a valorização do papel dos militares.

A tese de doutoramento do cientista político Alfred Stepan, apresentada à Universidade Columbia, em 1969, seria publicada no Brasil em 1975, com o título de Os militares na política: as mudanças de padrões na vida brasileira. Para Stepan, "a instituição militar não é um fator autônomo, mas deve ser pensada como um subsistema que reage a mudanças no conjunto do sistema político". Segundo ele, as razões imediatas do que (descuidadamente) chama de "revolução" derivavam da inabilidade de Goulart em "reequilibrar" ${ }^{26}$ o sistema político. Até 1964, teria havido no Brasil um padrão de relacionamento entre os militares e os civis caracterizável como "moderador", isto é, os militares somente eram chamados para depor um governo e transferi-lo para outro grupo de políticos civis, não assumindo efetivamente o poder, até porque não estariam convencidos da sua capacidade e legitimidade para governar (p.50). A singularidade da crise de 1964 estaria precisamente na capacidade que teve de transformar tal "padrão", pois, além da percepção de que as instituições civis estavam falhando, os militares também sentiram-se diretamente ameaçados em função da propalada quebra da disciplina e da hierarquia, su- 
posto passo inicial para a dissolução das próprias Forças Armadas, já que Goulart poderia dar um golpe com o apoio dos comunistas e, depois, não controlá-los mais. Além disso, critérios políticos para promoções no Exército sugeriam aos militares que Goulart teria a intenção de constituir, para fins golpistas, uma força militar que lhe fosse leal (ecoavam boatos sobre "exércitos populares" que não eram desmentidos pelo apoio de Goulart aos cabos, sargentos e suboficiais). Tudo isso teria levado à mudança do padrão, isto é, os militares passaram a supor a necessidade de um governo militar autoritário que pudesse fazer mudanças radicais e eliminar alguns atores políticos (p.124). Ademais, graças à doutrina de segurança nacional e ao treinamento desenvolvido pela Escola Superior de Guerra, haveria "dentro das Forças Armadas um nível de confiança relativamente elevado de que elas contavam com membros possuidores de uma solução relevante para os problemas brasileiros e que estavam tecnicamente preparados para governar" (p.137), ou seja, os militares passaram a sentir-se capacitados para assumir diretamente o governo.

As principais insuficiências históricas do livro de Alfred Stepan estavam na própria análise do chamado "padrão moderador", já que existiram interferências diretas dos militares na política brasileira antes de 1964 e é bastante problemática a visão do "subsistema militar" como "variável dependente" do sistema político global. ${ }^{27}$ Além disso, é relativamente superficial a análise histórica da ideologia militar anterior ao golpe. Além de tais fragilidades, a análise de Stepan também parece não dar conta integralmente do problema da heterogeneidade política dos militares: embora ele faça a distinção entre grupos que propõe sejam chamados de "internacionalistas liberais" (moderados) e "nacionalistas autoritários" (duros), tal tipologia não parece ter muita importância para a tese da "mudança de padrão", e não altera, a não ser nominalmente, a tipologia já consolidada na imprensa e na academia. Seja como for, Alfred Stepan apontou, corretamente, a necessidade de se estudar os militares considerando-se tanto suas interações com a sociedade quanto suas características específicas de grupo especializado.

A positividade maior do livro de Stepan consistia, curiosamente, na sua simples existência, isto é, na demonstração de que era possível pesquisar o tema, pois o autor valeu-se de material de algum modo acessível a todos (publicações oficiais e material jornalístico, principalmente), exceto talvez as entrevistas que obteve, para as quais contou com o fascínio que a figura do estrangeiro exerce em alguns brasileiros. Mas, além desse aspecto de ordem heurística, outro benefício de Os militares na política foi colaborar para a di- 
vulgação, notadamente entre os historiadores, das questões que animavam amplo debate na Ciência Política e na Sociologia.

O esforço da Ciência Política pelo estabelecimento de um padrão de sofisticação epistemológica - expresso na busca de um modelo teórico explicativo para as crises latino-americanas e/ou para os Estados submetidos a regimes militares - corre o risco de esbarrar no que poderia ser chamado de "fator histórico": as especificidades, as singularidades e as peculiaridades de sociedades distintas que, naturalmente, tendem a ser elididas quando se busca construir modelos explicativos com grande alcance de generalização. Este não foi o caso, porém, da interpretação de Wanderley Guilherme dos Santos. Suas análises sobre a crise de 1964 começaram a ser divulgadas em 1969, a partir da elaboração de um modelo teórico intitulado "competição política e cálculo do conflito". No início dos anos 70, capítulos de sua tese em preparação foram publicados abordando o desempenho do Legislativo no período 1959/1966 e a instabilidade governamental entre 1961/1964..$^{28}$ A tese, The calculus of conflict: impasse in Brazilian politics and crisis of 1964, seria apresentada à Universidade Stanford (EUA) em 1979. Reunindo novas análises e trabalhos reelaborados, o volume intitulado $O$ cálculo do conflito: estabilidade e crise na politica brasileira, recentemente publicado, ${ }^{29}$ é a melhor forma de conhecer a avaliação do autor sobre o assunto. É notável em seu trabalho tanto o esforço de elaboração teórica (o mencionado modelo para o cálculo de conflitos) quanto o rigoroso levantamento, sistematização e análise de dados empíricos. Esses dados estão dispostos em 85 tabelas e quatro gráficos; o modelo teórico encontra-se elaborado, até mesmo em termos lógico-formais, no primeiro de dois apêndices (o segundo registra uma breve tipologia das fontes e sucintas considerações heurísticas). Para Wanderley Guilherme dos Santos, "uma teoria em dieta factual não faz melhor figura do que uma narrativa teoricamente míope” (p.18).

As motivações iniciais do autor decorrem da insuficiência que ele identifica no "arcabouço convencional da análise política brasileira" (p.174), fundado na "hipótese de que os males de antanho, do presente e do porvir explicam-se pela incessante disputa em que se empenham grupos sociais adversários na conquista de bens materiais” (p.18). A crítica, de encontradiça coloração antimarxista, não implica o abandono total do "modelo consagrado": apenas faltariam ao "paradigma tradicional de análise" as "conexões intermediárias" de natureza política, pois não seria cabível fazer, a partir das variáveis econômicas e sociais, "ilações mecanicistas" sobre o sistema político (p.177).

A aplicação de tal paradigma à crise de 1964 seria inadequada, "a menos 
que sejam introduzidas variáveis políticas específicas” (p.174). Nesse sentido, Santos valoriza a leitura de Alfred Stepan, mas a considera insuficiente por não identificar o verdadeiro foco da disputa política, que estaria no padrão de coalizões no Congresso (p.173).

A hipótese central do modelo proposto por Santos afirma que, em sistemas polarizados, uma crise de paralisia decisória ocorre "quando os recursos de poder se dispersam entre atores radicalizados em suas posições", podendo se dar, então, "um colapso do sistema político, resultante de sua cadente capacidade operacional (isto é, de tomar decisões sobre questões conflitantes)" (p.22). Como se vê, o modelo não propõe uma explicação para golpes militares stricto sensu, mas busca esclarecer os processos de "crescente paralisia política, seguida de alguma forma de violência”, uma "mácula na ordem jurídica" (p.19). Assim, a crise brasileira de 1964 foi uma crise de paralisia decisória e o golpe teria sido fundamentalmente o resultado do emperramento do sistema político, antes que uma reação a iniciativas governamentais: "o golpe militar resultou mais da imobilidade do governo Goulart do que de qualquer política coerente por este patrocinada e executada" (p.202).

O Congresso brasileiro e a "estrutura política em geral" viviam uma crescente polarização, "isto é, uma divisão equilibrada de forças entre partidos politicamente diferentes”. Grupos radicalizados no interior de cada partido não sustentavam acordos políticos: "coalizões ad hoc, articuladas para impedir a adoção de políticas e não para servir como coalizões governamentais, tornam-se, em tais condições, um resultado altamente provável” (p.263). Note-se aí o fulcro da discordância de Santos em relação a Alfred Stepan, conforme mencionado há pouco, isto é, a fragmentação do apoio político não decorria da instabilidade das coligações eleitorais, mas das coalizações parlamentares.

As evidências empíricas trabalhadas por Santos são bastante expressivas e corroboram a impressão generalizada de que, na fase anterior a 1964, "o sistema político brasileiro havia ficado operacionalmente comprometido" (p.201). De fato, além de demonstrar quantitativamente a tendência decrescente da produção legal, que praticamente inviabilizou a resolução de qualquer assunto importante através de negociações parlamentares, Santos também chama a atenção para o fenômeno da rotatividade ministerial, talvez o melhor achado empírico de sua exaustiva pesquisa. As propostas reformistas de Goulart "requeriam complicadas alterações na Constituição de 1946, impossíveis sem a sustentação de sólida maioria parlamentar ... De outro lado, para conservar a liderança do amplo contingente esquerdista, o presidente 
era instado a declarar-se em antagonismo ao Congresso" (p.306). Daí decorriam as sucessivas substituições de titulares de ministérios. Conforme calculado por Santos, durante o governo de Jango foram observadas as maiores taxas de rotatividade ocorridas no Brasil pós-1946. Além dos ministérios, também as presidências de empresas e bancos estatais decisivos para o país (Petrobrás, Banco do Brasil, Banco Nacional de Desenvolvimento Econômico, Vale do Rio Doce e Siderúrgica Nacional) foram usadas por Goulart como moeda política, diferentemente de seus antecessores (p.328).

A crítica inicial de Santos ao "paradigma tradicional de análise" é confusa, pois não se define quanto ao objeto final de suas considerações: seriam insuficientes as teses (marxistas) que fazem prevalecer as estruturas econômicas e sociais em detrimento dos sistemas políticos ou o paradigma criticado seria apenas aquele que se refere à leitura do "populismo" como gerador do confronto entre executivos progressistas e legislativos controlados pela oligarquia rural? As duas críticas estão presentes e, em função disso, a imprecisão sobre qual seja o paradigma atacado — nada obstante seja possível deduzir a vinculação insinuada - destoa da demanda de precisão teórico-conceitual reclamada pelo próprio autor. Mais importante, a centralidade reivindicada para as "variáveis políticas" não enseja, em nenhum momento, uma definição precisa do que venha a ser a política ou o "sistema político". Em algumas passagens a política aparece referida apenas ao plano institucional de tomadas de decisões oficiais (Congresso e Executivo), em outras, abrange as ações (políticas?) de sindicatos e do próprio Exército (p.236 ss).

A grande massa de dados analisada por Santos corrobora aquilo que narrativas jornalísticas e históricas já haviam percebido: no período, o Legislativo estava praticamente paralisado e a instabilidade político-administrativa era evidente. O esforço de Wanderley Guilherme dos Santos poderia parecer, por isso, redundante, como se buscasse uma elaboração sofisticada e detalhista para um fato óbvio e consabido. Na verdade, entretanto, é meritório o empenho do autor, pois algumas narrativas históricas disponíveis baseiam-se em impressões e, conforme a crítica do autor, usam a expressão "paralisia decisória” como uma alegoria (p.202). Santos buscou demonstrá-la empiricamente a partir da melhor elaboração conceitual que logrou obter. Por certo que tal elaboração padece de alguma debilidade, quando, por exemplo, a paralisia decisória de 1964 se contrapõe à noção de "estabilidade do governo Kubitschek" (que, afinal, foi período vitimado por graves crises, inclusive militares, mesmo antes da posse).

A melhor contribuição do trabalho é chamar a atenção para a importân- 
cia das questões parlamentares, do Congresso, dos partidos políticos. Tal foco foi sistematicamente desprezado pela maioria dos analistas do regime militar. De fato, a literatura especializada, tendo enfatizado o papel dos empresários ou dos militares no golpe de 64 , tendeu, salvo raras exceções, a não considerar a dimensão político-institucional das crises do período no plano parlamentar. Exceção pode ser encontrada nas reflexões de Maria Celina D’Araujo, ${ }^{30}$ para a qual a "capacidade que o PTB teve de influenciar setores militares ou de interagir com eles foi certamente um dos principais fatores para a eclosão do golpe". ${ }^{31}$

A carência de análises político-institucionais talvez se explique pela grande dificuldade teórica de bem correlacionar os eventos da pequena política aos condicionantes estruturais. Argelina Cheibub Figueiredo, em sua tese de doutoramento em Ciência Política na Universidade de Chicago, em 1987, avalia que a ênfase de Santos "nos aspectos político-institucionais o leva a subestimar o caráter sócio-econômico dos problemas em jogo, no princípio dos anos 60, a saber, as 'reformas estruturais". ${ }^{32}$ A autora - expressando preocupações típicas de finais dos anos 80 - atribui grande importância à recusa das teses de algum modo deterministas, isto é, as que afirmavam a inevitabilidade do golpe a partir da consideração de algumas condições suficientes, sejam os fatores econômicos, ${ }^{33}$ sejam os políticos e institucionais, tal como estabelecido pela leitura de Santos. Ela recusa, igualmente, a centralidade do papel da "burguesia" na conspiração analisada por Dreifuss, já que a simples existência de uma conspiração não seria condição suficiente para o golpe (p.28). Finalmente, destaca o acerto da leitura de Stepan no que se refere ao momento final do governo de Goulart, quando o presidente, radicalizando sua posição, acabou por definitivamente erodir possíveis apoios. Ao contrário de Stepan, porém, Argelina Figueiredo chama a atenção para a necessidade de análise das "escolhas anteriores que haviam estreitado o leque de opções abertas à ação política” (p.28-9):

entre 1961 e 1964, escolhas e ações específicas solaparam as possibilidades de ampliação e consolidação de apoio para as reformas, e, desta forma, reduziram as oportunidades de implementar, sob regras democráticas, um compromisso sobre estas reformas. (p.30)

A recusa das leituras deterministas e a percepção da necessidade de articulação teórica entre eventos e estrutura não resulta, porém, numa explicação teórica, mas na hipótese empírica acima citada, caracterizando Democra- 
cia ou reformas? como um típico trabalho de História Política tradicional, aliás de alto nível, pois a pesquisa desenvolvida pela autora chama a atenção para episódios obscurecidos ou superficialmente tratados em outros trabalhos.

A Ciência Política de influência norte-americana, ao enfatizar os aspectos político-institucionais e as variáveis políticas, contrapunha-se às leituras marxistas que destacavam as determinações econômico-estruturais e os condicionamentos de classe. A discussão, por exemplo, sobre o grau de autonomia dos militares, vistos como corporação possuidora de dinâmica própria ou burocracia especializada, confrontava o possível entendimento marxista dos militares como agentes instrumentais da burguesia: para João Quartim de Moraes, por exemplo, "o que ocorreu em março-abril [de] 1964 foi um golpe reacionário da direita do qual os militares constituíram o instrumento decisivo" ${ }^{34}$ Do mesmo modo, se os regimes militares eram simples decorrência dos ajustes do capitalismo, o estudo específico dos militares pareceria menos importante, ganhando destaque, isto sim, os aspectos relacionados à expansão capitalista, ao capital internacional e ao papel dos setores da burguesia brasileira nesse contexto. ${ }^{35}$

Assim, até mesmo em função do predomínio acadêmico do marxismo, surgiu forte reação à corrente, passando a ser um "lugar-comum antimarxista" a crítica de que "as análises predominantes sobre o início dos anos 60 enfatizam os aspectos econômico-estruturais e concluem pela inevitabilidade do golpe". ${ }^{36} \mathrm{Na}$ verdade, nenhuma pesquisa acadêmica de fundo restringiu-se ao que poderíamos chamar de uma interpretação marxista economicista ortodoxa ou "vulgar", que descuidasse completamente dos aspectos políticos ou compartilhasse de um determinismo economicista absoluto. É certo, não obstante, que diversas avaliações marxistas genéricas, em debates, artigos de divulgação ou jornalísticos, enfatizavam o papel determinante de aspectos econômicos, como as necessidades de rearranjo decorrentes da relação entre o capital internacional e o nacional (associado). Além disso, importantes economistas já haviam chamado a atenção para o esgotamento da etapa "fácil" de substituição de importações ${ }^{37}$ e, com base neles, avaliações economicistas do golpe também foram feitas. ${ }^{38}$

A análise marxista mais conhecida sobre o golpe de 64 provém de Jacob Gorender. Combate nas trevas, livro divulgado em 1987, tinha por objetivo central o estudo da esquerda em geral e da luta armada em particular, mas o autor não deixou dúvidas sobre sua leitura de eventos correlacionados, como obviamente era o caso do golpe. Para ele, a explicação fundada no esgotamento do modelo de substituição de importações "só leva em conta o aspecto su- 
perficial e deriva da idéia de que o processo econômico se reduz a uma sucessão de modelos de política econômica". Ao contrário, "a crise econômica de 1962-1965 foi a primeira crise cíclica nascida no processo interno do capitalismo brasileiro e revelou precisamente o seu amadurecimento". ${ }^{39}$ Segundo o autor, tendo em vista a já inconteste proeminência da burguesia industrial, o enfrentamento da crise impunha-se como adesão aos parâmetros de estabilização financeira tal como preceituados pelo Fundo Monetário Internacional — FMI. Porém, "a receita recessiva requer governos fortes, capazes de negar concessões às massas trabalhadoras e forçá-las a engolir o purgante das medidas compressoras do nível de vida" (p.42). Ora, a mobilização em torno das reformas estruturais (ou "reformas de base") não apontava nesse sentido:

O núcleo burguês industrializante e os setores vinculados ao capital estrangeiro perceberam os riscos dessas virtualidades das reformas de base e formularam a alternativa da "modernização conservadora". Opção que se conjugou à conspiração golpista. (p.51)

Diferentemente de outros autores, que preferem indicar a inexistência de riscos maiores de efetiva vitória da esquerda, Gorender enfatiza que, no pré-64, engendrou-se uma real "ameaça à classe dominante brasileira e ao imperialismo":

o período 1960-1964 marca o ponto mais alto das lutas dos trabalhadores brasileiros neste século $[\mathrm{XX}]$. O auge da luta de classes, em que se pôs em xeque a estabilidade institucional da ordem burguesa sob os aspectos do direito de propriedade e da força coercitiva do Estado. Nos primeiros meses de 1964, esboçou-se uma situação pré-revolucionária e o golpe direitista se definiu, por isso mesmo, pelo caráter contra-revolucionário preventivo. A classe dominante e o imperialismo tinham sobradas razões para agir antes que o caldo entornasse. (p.66-7)

Portanto, Gorender consolidou, em traços gerais, duas das principais linhas de força interpretativas sobre as razões do golpe: o papel determinante do estágio em que se encontrava o capitalismo brasileiro e o caráter preventivo da ação, tendo em vista reais ameaças revolucionárias provindas da esquerda.

Uma análise que partiu dos pressupostos marxistas, e que não pode ser chamada de economicista, foi a de René Armand Dreifuss, cientista político uruguaio, também formado em história, que se doutorou em 1980, na Universidade de Glasgow, com a tese State, class and the organic elite: the forma- 
tion of the entrepreneurial order in Brazil, 1961-1965. A tese se transformaria no livro, publicado no Brasil em 1981, 1964: a conquista do Estado. Ação política, poder e golpe de classe, um best seller. Diferentemente de outros cientistas políticos, Dreifuss advertia que generalizações sobre "Estados burocráticoautoritários" exigiriam pesquisa comparativa, chamando a atenção para a especificidade do caso brasileiro.

Dreifuss parte do pressuposto de que o domínio econômico do capital multinacional na economia brasileira não encontrava uma correspondente liderança política: "havia uma clara assimetria de poder entre a predominância econômica do bloco multinacional e associado, que se consolidara durante os períodos de Juscelino Kubitschek e Jânio Quadros, e sua falta de liderança política". ${ }^{40}$ Assim, contrapondo-se à proeminência política, de tipo "populista", da burguesia tradicional e de setores oligárquicos, tal bloco "organizou grupos de pressão e federações profissionais de classe, escritórios técnicos e anéis burocrático-empresariais, com o objetivo de conseguir que seus interesses tivessem expressão a nível de governo" (p.104). Como se vê, há aí discordância significativa com a análise de Gorender, para o qual o vetor da luta política não estava na conquista da hegemonia pela fração multinacional-associada da burguesia, mas na substituição do controle de tipo "populista" das classes populares por outro decididamente coercitivo.

Partindo dos pressupostos de Gramsci sobre as formas civis e militares de organização do poder de classe, Dreifuss descreveu, detalhadamente, as atividades das organizações empresariais Ipes - Instituto de Pesquisas e Estudos Sociais e Ibad — Instituto Brasileiro de Ação Democrática, amparando-se em documentação que ele teria encontrado, casualmente, no Arquivo Nacional. O "complexo Ipes/Ibad" teria funcionado como um "Estado-Maior da burguesia multinacional-associada [que] desenvolveu uma ação medida, planejada e calculada que a conduziu ao poder” (p.145). Para além de caracterizar a busca de liderança do processo político, a atuação dessas associações também indicou ao "bloco multinacional e associado" a necessidade de um golpe de Estado, já que tentativas anteriores de reforma dentro da lei haviam fracassado. Politicamente, às forças identificadas com os "interesses multinacionais e associados" faltava, "se não o apelo ideológico-programático, pelo menos a estrutura clientelista de apoio popular" (p.146). Daí a inevitabilidade do golpe, único caminho para que tais interesses assomassem ao poder.

Dreifuss mostrou, em minúcias, que o "complexo Ipes/Ibad" atuava de maneira bastante variada, em diversas frentes de atuação, mobilizando equipes multifuncionais, espraiando-se virtualmente por todo o país e amparan- 
do-se em recursos e financiamentos razoavelmente abundantes. Tratava-se de uma ampla campanha de desestabilização. Assim,

embora o bloco modernizante-conservador fosse incapaz de se impor por consenso na sociedade brasileira, ele, no entanto, era capaz, através de sua campanha ideológica, de esvaziar uma boa parte do apoio ao Executivo existente e reunir as classes médias contra o governo. (p.259)

Essa ação ideológica, entretanto, não seria suficiente para levar a uma troca de regime. Foi preciso construir uma rede de apoio dentro das Forças Armadas e, por essa razão, alguns dos mais destacados associados ao Ipes e ao Ibad foram oficiais dos mais influentes na época. Tendo estimulado uma atmosfera de inquietação política, conseguiram "coordenar e integrar os vários grupos militares, conspirando contra o governo, e, de certa forma, proporcionar o exigido raciocínio estratégico para o golpe" (p.338). Seus ativistas participaram diretamente da conspiração militar. Desse modo, segundo Dreifuss, o que se viu em 1964 não foi um golpe das Forças Armadas contra João Goulart, mas a "culminância de um movimento civil-militar" (p.361). Como argumento final, e contrapondo-se à visão de que os governos militares seriam conduzidos por uma tecnocracia imparcial e apartidária, Dreifuss indica que, em vários casos, importantes cargos do governo de Castelo Branco foram dados a "homens-chave dos grandes empreendimentos industriais e financeiros e de interesses multinacionais": seria a plena realização dos interesses do "bloco multinacional e associado" (p.455).

Como se vê, René Armand Dreifuss fazia uma leitura marxista clássica, defendendo a existência de um longo processo de luta política de um setor de classe, ou de um bloco de poder, pela implementação de seus interesses, conscientemente defendidos. Embora o jargão mobilizado por Dreifuss ecoe um determinismo de fato presente em outras análises marxistas de perfil ortodoxo, no caso de seu livro os fatores estruturais referidos ao capital internacional não "geram", sem mediações, o golpe de 64. Ao contrário, segundo o autor verificou-se todo um processo complexo e progressivo de preparação, no plano político, que durou anos e mobilizou vultosos recursos. Discordando de Alfred Stepan, Dreifuss advoga que os agentes do golpe de 64 não foram as Forças Armadas ou a doutrinação isolada da Escola Superior de Guerra, havendo, pois, a necessidade de sublinhar — como o fez — a importância dos empresários, em geral minimizados por conta da visão "autônoma ou subsistêmica das Forças Armadas e da tecnoburocracia” (p.486). Desse modo, não 
foi um suposto "aparelho militar-burocrático" que tomou o poder, a despeito das classes dominantes, para que, afinal, pudesse fazer prevalecer os interesses dessas classes: na verdade o Estado teria sido diretamente reorganizado pela "elite orgânica" capitaneada pelo Ipes.

Também Daniel Aarão Reis Filho esposaria essa tese, segundo a qual o golpe de 64 veio para "reforçar a hegemonia do capital internacional no bloco do poder" ${ }^{41}$ e só foi possível graças ao caráter amplo e heterogêneo da frente social e política que se reuniu para depor Goulart. Tal amplitude (banqueiros, empresários, industriais, latifundiários, comerciantes, políticos, magistrados e classe média) "condicionaria, no interior das Forças Armadas, uma unidade que seria dificilmente concebível em condições 'normais”” (p.57) e fundava-se na compartilhada "aversão ao protagonismo crescente das classes trabalhadoras na história republicana brasileira depois de 1945 ”. ${ }^{2}$ Mas Reis Filho chama a atenção para o que, de fato, é a fragilidade maior do trabalho de Dreifuss, isto é, a superestimação da capacidade que aquelas associações teriam de conduzir o processo histórico. Ademais, não é razoável supor que a classe média apenas recebesse, passivamente, as mensagens ideológicas do Ipes/Ibad: elas "percebiam que um processo radical de distribuição de renda e de poder por certo afetaria suas tradicionais posições e seus relativos privilégios naquela sociedade brutalmente desigual".43

Porém, se a preparação do golpe foi de fato "civil-militar", no golpe, propriamente, sobressaiu o papel dos militares. Além das movimentações de tropas, desde o início do regime foi indiscutível a preponderância dos militares, em detrimento das lideranças golpistas civis. Por certo, como demonstrou Dreifuss, importantes cargos do primeiro escalão foram destinados aos ipesianos civis e, mais importante, a política econômica do primeiro governo militar pautou-se pelos ditames do saneamento financeiro que interessava ao capital internacional. Mas as sucessivas crises do período foram resolvidas manu militari e a progressiva institucionalização do aparato repressivo também demonstra a feição militar do regime. Do mesmo modo, sucessivas levas de militares passaram a ocupar cargos em importantes agências governamentais. Se podemos falar de um golpe civil-militar, trata-se, contudo, da implantação de um regime militar - em duas palavras: de uma ditadura militar.

Gláucio Ary Dillon Soares reclamaria a necessidade de atenção precisamente para o papel dos militares. Segundo ele

As interpretações iniciais do golpe militar enfatizaram suas causas econômicas, em parte devido à predisposição genérica de aceitar explicações econômi- 
cas, em parte devido à relativa simultaneidade do fim da etapa fácil da substituição de importações e da eclosão de regimes militares na América Latina. O economicismo do pensamento político e social na América Latina fez com que se fosse buscar nas elites econômicas os responsáveis pelo golpe. O golpe, porém, foi essencialmente militar: não foi dado pela burguesia ou pela classe média, independentemente do apoio que estas lhe prestaram. ${ }^{44}$

A crítica de Soares visava essencialmente à "tradição, de origem marxista, profundamente arraigada na sociologia política latino-americana, que penetra inclusive na ciência social mais conservadora, de privilegiar as explicações econômicas e subestimar as demais" (p.10). Em função do papel preponderante que, nessa tradição, "eurocêntrica" e "gerada no século XIX", assumiam os conflitos bipolares entre burguesia e proletariado, "a autonomia dos militares foi sistematicamente subestimada" (p.12, grifado no original), daí resultando uma produção sociológica e política "livresca" e carente de pesquisas específicas sobre a realidade brasileira. Dessas críticas decorrem a avaliação de insuficiência de análises, por exemplo, como as de Fernando Henrique Cardoso (sobre a necessidade de desbaratamento dos mecanismos populares de pressão decorrentes do processo de acumulação) ou de Guillermo O’Donnell (segundo o qual a passagem para uma etapa competitiva da "industrialização substitutiva de importações" teria demandado regimes burocrático-autoritários).

$\mathrm{Na}$ análise de Soares transparece alguma insatisfação com a tese da "conquista do Estado" pelo Ipes e congêneres: pesquisando depoimentos escritos por militares (p.28 ss), ele destacou que o golpe foi preponderantemente uma "conspiração dos militares com apoio dos grupos econômicos brasileiros" (p.34-5), e não uma conspiração dos grupos econômicos com o apoio dos militares, embora esta última "seja uma das explicações favoritas na literatura política e sociológica sobre o golpe” (p.35). Além disso, duas avaliações também correntes (conspiração de grupos econômicos brasileiros com apoio das multinacionais ou dos Estados Unidos) "não mereceram uma só menção dos militares consultados, demonstrando que há um divórcio entre a caracterização do golpe pela literatura político-sociológica e a percepção do que foi o golpe por parte dos próprios militares” (p.35).

Diferentemente de Dreifuss, para quem os aspectos explicativos preponderantes resultam da articulação dos empresários em torno do Ipes tendo em vista a defesa dos interesses do capital internacional e associado, para Soares o importante é destacar as motivações dos militares para o golpe, que se cir- 
cunscreveriam em três blocos de preocupações: (a) o caos administrativo e a desordem política; (b) o perigo comunista e esquerdista em geral e (c) os ataques à hierarquia e à disciplina militares (p.32). Assim, tomando por base os livros publicados e as entrevistas concedidas pelos militares, Soares conclui que "a concordância entre militares de diferentes orientações políticas e de diferentes armas a respeito do papel secundário que os fatores econômicos desempenharam não deixa lugar a dúvida: o golpe de 64 foi um golpe essencialmente político" (p.45, grifado no original). A afirmativa resulta algo desconcertante, pois a ninguém ocorreu classificar o golpe de "econômico", muito embora Dreifuss tenha destacado o papel dos interesses do capital internacional como motivador da luta política de empresários e ipesianos em geral, tanto quanto opiniões menos densas tenham quase que exclusivamente destacado o papel determinante do estágio de então do capitalismo. Ademais, é natural que haja discrepância entre a percepção dos sujeitos históricos e as análises que, a posteriori, se possam fazer.

Nada obstante, o estudo da memória militar chama a atenção para aspectos complexos do processo histórico que culminou no golpe, dentre os quais sobreleva o caráter aparentemente disperso da conspiração. De fato, para Dreifuss, o golpe resultou de uma articulação conspiratória centralizada no "complexo Ipes/Ibad", como já foi visto. Porém, segundo Soares, o que houve foi um "caos conspiratório", pois a coordenação entre os grupos em diferentes pontos do país era pequena e, algumas vezes, na mesma cidade, grupos militares diferentes conspiravam sem maior articulação (p.47-8). A própria iniciativa de Mourão sublinha essa falta de uma coordenação centralizada, ao contrário da leitura de Dreifuss.

Avaliações como a de Soares confluíram para uma iniciativa de pesquisa que se revelaria fundamental para o estudo do golpe de 64 e da ditadura militar. Levadas a cabo por pesquisadores do CPDOC - Centro de Pesquisa e Documentação de História Contemporânea do Brasil, da Fundação Getúlio Vargas, várias entrevistas com militares foram feitas. ${ }^{45} \mathrm{Em} \mathrm{1994}$, a equipe do CPDOC divulgou o primeiro dos três volumes de entrevistas de militares que “em sua maioria não tiveram uma liderança destacada nos preparativos do golpe. Foram, no entanto, peças importantes na implementação e manutenção do regime". ${ }^{46}$

As entrevistas confirmavam a percepção militar majoritária da importância do anticomunismo e do mal-estar com a suposta quebra da hierarquia e da disciplina e, com elas, o aspecto da percepção militar sobre o papel dos civis e dos militares ficaria bastante esclarecido, pois, se havia óbvio relacio- 
namento entre os ativistas do Ipes e os militares, a decisão de movimentar tropas, que é, afinal, o gesto capaz de deflagrar o golpe, dependia de considerações especificamente militares, sendo visível, por exemplo, para os generais conspiradores, a importância do papel (militar) da decisão do colega Amaury Kruel, general comandante do II Exército, de aderir ou não ao movimento. Aspectos como poder de fogo, eficiência ou precariedade de armamentos disponíveis, tamanho das tropas etc. eram evidentemente importantes e, embora o movimento tenha se consumado sem a necessidade de confrontações militares efetivas, é claro que estas considerações estavam na mente dos generais golpistas.

Além disso, os depoimentos mostram que, para os militares, o golpe decorreu de uma conspiração desarticulada, visão que, segundo os organizadores,

se contrapõe à interpretação predominante entre os analistas que até agora examinaram o episódio. Para estes, o golpe teria sido produto de um amplo e bemelaborado plano conspiratório que envolveu não apenas o empresariado nacional e os militares, mas também forças econômicas multinacionais. ${ }^{47}$

Também para o historiador marxista Jacob Gorender, a conspiração foi descentralizada: "é uma idéia falsa a de que os golpistas estivessem fortemente articulados. Pelo contrário, a articulação era frouxa e havia muita desconexão" ${ }^{48}$ Argelina Figueiredo, além disso, chama a atenção para o fato de que "a conspiração foi uma condição necessária mas não suficiente para o sucesso do golpe de 1964". ${ }^{49}$

Sem a desestabilização (propaganda ideológica, mobilização da classe média etc.) o golpe seria bastante difícil; sem a iniciativa militar, impossível. Portanto, é preciso bem distinguir a atuação desestabilizadora (a propaganda do Ipes e outras agências) da conspiração golpista civil-militar, que em muitos momentos não passou de retórica radical e somente se consolidou às vésperas do 31 de março. Assim, creio não ser abusivo afirmar o acerto histórico da leitura segundo a qual a "desestabilização civil" foi bastante articulada, mas a ação militar não foi inteiramente planejada, com segurança e sistematicidade, ficando à mercê de iniciativas de algum modo imprevistas:

Espalhavam-se as conspirações, de norte a sul do país. Num primeiro momento, fragmentadas; mais tarde, unificando-se, numa rede complexa, não de todo centralizada, mas com certo nível de coordenação. Com propósitos aparentemente defensivos, começaram a preparar um bote ofensivo. ${ }^{50}$ 
As pesquisas conduzidas pela equipe do CPDOC também serviram para esclarecer a pouca importância atribuída pelos militares ao apoio militar norte-americano, por vezes supervalorizado em algumas análises brasileiras, como critica Soares. ${ }^{51}$ Além de apontar a importância da consideração da especificidade dos militares, as entrevistas realizadas pela equipe do CPDOC trouxeram outras revelações valiosas que elevaram o patamar do conhecimento histórico sobre o tema. No que se refere estritamente ao período do golpe, podem ser destacados aspectos como a falta de uma liderança militar durante o período da conspiração ("todos teriam passado grande parte da conspiração à procura de líderes" $)^{52}$ e a virtual inexistência de um projeto de governo: "a questão imediata, segundo a maioria dos relatos, era tirar Jango e fazer uma 'limpeza' nas instituições”. ${ }^{53}$

As transformações estruturais do capitalismo brasileiro, a fragilidade institucional do país, as incertezas que marcaram o governo de João Goulart, a propaganda política do Ipes, a índole golpista dos conspiradores, especialmente dos militares - todas são causas, macroestruturais ou micrológicas, que devem ser levadas em conta, não havendo nenhuma fragilidade teórica em considerarmos como razões do golpe tanto os condicionantes estruturais quanto os processos conjunturais ou os episódios imediatos. Que uma tal conjunção de fatores adversos — esperamos todos — jamais se repita.

\section{NOTAS}

${ }^{1}$ As pesquisas do autor contam com o apoio do CNPq e da Faperj. O presente artigo reproduz alguns aspectos tratados em FICO, C. Além do golpe: versões e controvérsias sobre 1964 e a Ditadura Militar. Rio de Janeiro: Record, 2004.

${ }^{2}$ FERREIRA, J. O trabalhismo radical e o colapso da democracia no Brasil. Comunicação apresentada no "Seminário 40 Anos do Golpe". Rio de Janeiro: UFRJ, UFF, CPDOC, APERJ, 22 mar. 2004.

${ }^{3}$ REIS FILHO, D. A. Ditadura militar e sociedade: as reconstruções da memória. Comunicação apresentada no Ciclo de Palestras Pensando 1964. São Paulo: Centro Cultural Banco do Brasil. 1 abr. 2004.

${ }^{4}$ VILLA, M. A. Jango: um perfil (1945-1964). São Paulo: Globo, 2004.

${ }^{5}$ GASPARI, E. A ditadura derrotada. São Paulo: Companhia das Letras, 2003, p.324.

${ }^{6}$ FICO, C. Como eles agiam. Os subterrâneos da Ditadura Militar: espionagem e polícia política. Rio de Janeiro: Record, 2001. 
${ }^{7}$ LAPA, J. R. do A. A história em questão (historiografia brasileira contemporânea). Petrópolis: Vozes, 1976.

${ }^{8}$ IGLÉSIAS, F. Melancólica trajetória nacional. Jornal do Brasil. 23 mar. 1994. Primeiro caderno, p.11.

${ }^{9}$ Ver SKIDMORE, T. Brasil: de Getúlio Vargas a Castelo Branco (1930-1964). Rio de Janeiro: Saga, 1969 (a edição norte-americana é de 1966).

${ }^{10}$ VIANA FILHO, L. O governo Castelo Branco. Rio de Janeiro: J. Olympio, 1975. KRIEGER, D. Desde as Missões... saudades, lutas, esperanças. Rio de Janeiro: J. Olympio, 1976.

${ }^{11}$ MELLO, J. P. A revolução e o governo Costa e Silva. Rio de Janeiro: Guavira, 1979. ABREU, H. O outro lado do poder. Rio de Janeiro: Nova Fronteira, 1979.

${ }^{12}$ GABEIRA, F. O que é isso, companheiro? Rio de Janeiro: Codecri, 1979. SIRKIS, A. Os carbonários: memórias da guerrilha perdida. São Paulo: Global, 1980.

${ }^{13}$ GORENDER, J. Prefácio. In: FICO, C., op. cit., p.13.

${ }^{14}$ Ver a melhor biografia do primeiro general-presidente recentemente publicada: LIRA NETO. Castello: a marcha para a ditadura. São Paulo: Contexto, 2004.

${ }^{15}$ A expressão foi proposta por Maria Celina D’Araujo, Celso Castro e Gláucio Ary Dillon Soares. Ver D'ARAUJO, M. C. et al. (Org.) Visões do golpe: a memória militar sobre 1964. Rio de Janeiro: Relume-Dumará, 1994, p.9.

${ }^{16}$ FICO, C. Além do golpe: versões e controvérsias sobre 1964 e a Ditadura Militar. Rio de Janeiro: Record, 2004, p.83.

${ }^{17}$ Neste trabalho, uso a expressão "linha dura" para caracterizar os grupos militares e civis diretamente envolvidos com as comunidades de segurança e de informações.

${ }^{18}$ KLEIN, L., FIGUEIREDO, M. F. Legitimidade e coação no Brasil pós-64. Rio de Janeiro: Forense-Universitária, 1978, p.46-7. OLIVEIRA, E. R. As Forças Armadas: política e ideologia no Brasil (1964-1969). Petrópolis: Vozes, 1976, p.105. STEPAN, A. C. Os militares: da Abertura à Nova República. Rio de Janeiro: Paz e Terra, 1986, p.21.

${ }^{19}$ FICO, C. Como eles agiam. Os subterrâneos da Ditadura Militar: espionagem e polícia política. Rio de Janeiro: Record, 2001, p.123 ss.

${ }^{20}$ Ernesto Geisel disse: "esse negócio de matar é uma barbaridade, mas eu acho que tem que ser”. GASPARI, E. A ditadura derrotada. São Paulo: Companhia das Letras, 2003, p.324.

${ }^{21}$ O sistema foi implantado em 1970 no I Exército (Rio de Janeiro), no II Exército (São Paulo), no IV Exército (Recife) e no Comando Militar do Planalto (Brasília). No ano seguinte, seriam criados os da $5^{a}$ Região Militar (Curitiba), da 4a Divisão de Exército (Belo Horizonte), da $6^{\mathrm{a}}$ Região Militar (Salvador), da $8^{\mathrm{a}}$ Região Militar (Belém) e da $10^{\mathrm{a}}$ Região Militar (Fortaleza). Em 1974 foi implantado o de Porto Alegre (III Exército).

${ }^{22} \mathrm{~A}$ censura à imprensa foi admitida pelo governo Médici como "revolucionária" (isto é, ba- 
seada no AI-5) em 1973, durante o julgamento, pelo STF, de um mandado de segurança impetrado pelo jornal Opinião. O episódio está descrito em SMITH, A.-M. Um acordo forçado: o consentimento da imprensa à censura no Brasil. Rio de Janeiro: FGV, 2000, p.130-2.

${ }^{23}$ FICO, C. "Prezada Censura". Cartas ao regime militar. Topoi, Rio de Janeiro, n.5, p.25186, set. 2002.

${ }^{24}$ Sobre o tema ver FICO, C. Reinventando o otimismo: ditadura, propaganda e imaginário social no Brasil (1969-1977). São Paulo, 1996. Tese (Doutorado) - USP.

${ }^{25}$ Veja relação completa e outras informações em FICO, C. Além do golpe: versões e controvérsias sobre 1964 e a Ditadura Militar. Rio de Janeiro: Record, 2004, p.139 ss.

${ }^{26}$ STEPAN, A. C. Os militares na política: as mudanças de padrões na vida brasileira. Rio de Janeiro: Artenova, 1975, p.140.

${ }^{27}$ Ver a análise crítica, superiormente conduzida, de João Roberto Martins Filho, para o qual essa não é a principal fragilidade da obra de Stepan, mas sua visão dos militares como uma elite burocrática. Martins Filho cita diversos autores que criticaram a obra de Stepan, inclusive no que se refere à refutação do padrão moderador. MARTINS FILHO, J. R. O palácio e a caserna: a dinâmica militar das crises políticas na ditadura (1964-1969). São Carlos: EDUFSCar, 1995, p.28 ss. Ver, especialmente, CARVALHO, J. M. de. As Forças Armadas na Primeira República: o poder desestabilizador. In: FAUSTO, B. (Dir.) O Brasil republicano. História Geral da Civilização Brasileira, t.III, v.2. 2.ed. Rio de Janeiro: Difel, 1978, p.181-256.

${ }^{28}$ SANTOS, W. G. dos. Paralisia da decisão e comportamento legislativo: a experiência brasileira, 1959-1966. Revista de Administração de Empresas, v.13, n.2, abr./jun. 1973; e, do mesmo autor, Coalizões parlamentares e instabilidade governamental: a experiência brasileira — 1961/1964. Revista de Administração de Empresas, v.13, n.4, out./dez. 1973.

${ }^{29}$ SANTOS, W. G. dos. O cálculo do conflito: estabilidade e crise na política brasileira. Belo Horizonte, Rio de Janeiro: Ed. UFMG, Iuperj, 2003.

${ }^{30}$ D’ARAUJO, M. C. A ilusão trabalhista: o PTB de 1945 a 1965. Rio de Janeiro, 1989. Tese (Doutorado) - Iuperj; e, da mesma autora, Raízes do golpe: ascensão e queda do PTB. In: SOARES, G. A. D., D’ARAUJO, M. C. (Org.) 21 anos de regime militar: balanços e perspectivas. Rio de Janeiro: Fundação Getúlio Vargas, 1994.

${ }^{31}$ D’ARAUJO, M. C. Raízes do golpe: ascensão e queda do PTB. In: SOARES, G. A. D., D'ARAUJO, M. C. (Org.), op. cit., p.69.

${ }^{32}$ FIGUEIREDO, A. C. Democracia ou reformas? Alternativas democráticas à crise política: 1961-1964. São Paulo: Paz e Terra, 1993, p.25.

${ }^{33}$ As leituras criticadas são as de O'DONNEL, G. Modernización y autoritarismo. Buenos Aires: Paidós, 1972; do mesmo autor, Reflexiones sobre las tendencias generales de cambio en el Estado Burocratico-Autoritário. Buenos Aires: Cedes/Clacso. Documento no 1, 1975; e de CARDOSO, F. H. Associated-dependent development: theoretical and practical im- 
plications. In: STEPAN, A. (Ed.) Authoritarian Brazil. New Haven: Yale University Press, 1973.

${ }^{34}$ MORAES, J. Q. de. O colapso da resistência militar ao golpe de 64. In: TOLEDO, C. N. de (Org.) 1964: visões críticas do golpe: democracia e reformas no populismo. São Paulo: Unicamp, 1997, p.131.

${ }^{35}$ OLIVEIRA, F. de. Dilemas e perspectivas da economia brasileira no pré-64. In: TOLEDO, C. N. de. (Org.) 1964: visões críticas do golpe. Democracia e reformas no populismo. Campinas: Unicamp, 1997, p.26.

${ }^{36}$ FIGUEIREDO, A. C. Democracia \& reformas: a conciliação frustrada. In: TOLEDO, C. N. de. (Org.), op. cit., p.47.

${ }^{37}$ TAVARES, M. da C. Auge y declinación del proceso de sustitución de importaciones en el Brasil. Boletín Económico de América Latina, v.9, n.1, mar. 1964; e FURTADO, C. Desarrollo y estancamiento en América Latina: un enfoque estructuralista. Desarrollo Económico, v.6, n.22-23, 1966.

${ }^{38}$ Ver crítica em SOARES, G. A. D. O Golpe de 64. In: SOARES, G. A. D., D’ARAUJO, M. C. (Org.), op. cit., p.13.

${ }^{39}$ GORENDER, J. Combate nas trevas. A esquerda brasileira: das ilusões perdidas à luta armada. São Paulo: Ática, 1987, p.41-2.

${ }^{40}$ DREIFUSS, R. A. 1964: A conquista do Estado: ação política, poder e golpe de classe. Rio de Janeiro: Vozes, 1981, p.105.

${ }^{41}$ REIS FILHO, D. A. A revolução faltou ao encontro: os comunistas no Brasil. São Paulo, Brasília: Brasiliense, CNPq, 1990 [1989?], p.22.

${ }^{42}$ REIS FILHO, D. A. O colapso do colapso do populismo ou a propósito de uma herança maldita. In: FERREIRA, J. (Org.), op. cit., p.344. Para Caio Navarro de Toledo, "pode-se afirmar que a crise econômica e o avanço político-ideológico das classes trabalhadoras e populares passavam a ser encarados [pela burguesia brasileira] como realidades sociais inaceitáveis". TOLEDO, C. N. de. 1964: o golpe contra as reformas e a democracia populista. Revista de Sociologia e Política, Curitiba, n.2, p.33, jun. 1994.

${ }^{43}$ REIS FILHO, D. A. O colapso do colapso do populismo ou a propósito de uma herança maldita. In: FERREIRA, J. (Org.), op. cit., p.332, nota 5 e p.335.

${ }^{44}$ SOARES, G. A. D. O Golpe de 64. In: SOARES, G. A. D., D’ARAUJO, M. C. (Org.), op. cit., p.27, grifado no original.

${ }^{45}$ Veja detalhes sobre os projetos que conduziram as entrevistas em D’ARAUJO, M. C., SOARES, G. A. D., CASTRO, C. (Org.) Visões do golpe. A memória militar sobre 1964. Rio de Janeiro: Relume-Dumará, 1994, p.8; e em SOARES, G. A. D., op. cit., p.28 ss.

${ }^{46}$ D'ARAUJO, M. C., SOARES, G. A. D., CASTRO, C. (Org.), op. cit., p.8, grifado no original. Esse primeiro volume abrange o período compreendido entre a renúncia de Jânio 
Quadros e a eleição de Costa e Silva. Os demais são, dos mesmos organizadores, Os anos de chumbo: a memória militar sobre a repressão. Rio de Janeiro: Relume-Dumará, 1994; e A volta aos quartéis: a memória militar sobre a abertura. Rio de Janeiro: Relume-Dumará, 1995.

${ }^{47}$ D’ARAUJO, M. C., SOARES, G. A. D., CASTRO, C. (Org.) Visões do golpe. A memória militar sobre 1964. Rio de Janeiro: Relume-Dumará, 1994, p.16.

${ }^{48}$ GORENDER, J. Era o golpe de 64 inevitável? In: TOLEDO, C. N. de. (Org.) 1964: visões críticas do golpe: democracia e reformas no populismo. São Paulo: Unicamp, 1997, p.112.

${ }^{49}$ FIGUEIREDO, A. C. Democracia ou reformas? Alternativas democráticas à crise política: 1961-1964. São Paulo: Paz e Terra, 1993, p.171.

${ }^{50}$ REIS FILHO, D. A. O colapso do colapso do populismo ou a propósito de uma herança maldita. In: FERREIRA, J. (Org.), op. cit., p.332.

${ }^{51}$ SOARES, G. A. D. O Golpe de 64. In: SOARES, G. A. D., D'ARAUJO, M. C. (Org.), op. cit., p.45.

${ }^{52}$ D’ARAUJO, M. C., SOARES, G. A. D., CASTRO, C. (Org.), op. cit., p.17.

${ }^{53}$ Ibidem, p. 18. 